Vaishali S. Dhingra ${ }^{1 *}$, Hemantkumar P. Bulsara ${ }^{2}$, Shailesh Gandhi ${ }^{3}$ 1S.V.National Institute of Technology (SVNIT), Surat, India 2S.V.National Institute of Technology (SVNIT), Surat, India 3Indian Institute of Management (IIM), Ahmedabad, India

\title{
Forecasting Foreign Institutional Investment Flows towards India Using ARIMA Modelling
}

\author{
UDC: $339.727 .22(540)$ \\ $005.22: 330.322$ \\ DOI: 10.7595/management.fon.2015.0009
}

\begin{abstract}
India has witnessed substantial increase in capital flows, particularly Foreign Institutional Investment in equity as well as derivatives segment since the 1990s. However, Fll flows are sighted as 'hot money'- more volatile than other type of flows, which gets affected by the domestic and global- macro economic factors, thereby raising questions about the need to encourage Fll flows in narrow and shallow (in terms of absorption capacity) capital market such as India. This paper attempts to forecast daily Aggregate FII flow in Indian Capital market and particularly in Futures Market (Derivative Segment) using Auto Regressive Integrated Moving Average (ARIMA) model.The paper tries to examine Fll flows in India towards futures market along with spot market by tracing which AR terms and/or MA terms influence the current inflow or outflow.
\end{abstract}

Keywords: Foreign Institutional Investment, Indian stock market, hot money, Futures market, Auto Regressive Integrated Moving Average (ARIMA)

\section{Introduction}

"The Only Thing That Is Constant Is Change - By Heraclitus" is valid even in the case of ever changing and dynamic capital markets of world economies and India is no exception. A significant amount of capital flows are towards emerging economies from developed nations in search of higher yield. Earlier, during the inception of globalization, liberalization and privatisation, most portions of the capital flows took the form of official grants and aid, which was later subdued by commercial borrowings. As a result of governments' efforts, non-debt creating flows in the form of Foreign Direct Investment and Foreign Institutional Investment also gained momentum along with commercial borrowings. India's share in net portfolio flows to emerging market and developing countries has grown in similar pattern to FDI. In contrast to developing and emerging market economies in most parts of the world, where FDI has constituted the main source of equity flows, India has witnessed a dominance of portfolio flows over FDI flows during various periods of time. However, not like FDI flows which exhibited more or less steady upward movement over the years, portfolio flows are more volatile and disrupting, moving in tandem with domestic and international market sentiments. A sharp rise in portfolio investment into India in the recent period reflects both global and domestic factors. The quest for yield in view of very low real long-term rates in advanced economies has been an important factor driving portfolio flows to EMEs and as a part of that group, India also has attracted such flows.

\footnotetext{
1 Faculty of Economics and Management, Management Section, AppliedMathematics and HumanitiesDepartment, SardarVallabhbhai National Institute of Technology, Surat, Gujarat-395007, India; (M) 91-9913656187; E-mail: vaishalidhingra1@gmail.com. ${ }^{2}$ Assistant Professor (Economics\& Management), Management Section, AppliedMathematics and HumanitiesDepartment, SardarVallabhbhai National Institute of Technology, Surat, Gujarat-395007, India; (M) 91- 9825535673; E-mail: hemantbulsara@gmail.com. ${ }^{3}$ Associate Professor (Finance \& Accounting), Indian Institute of Management, Ahmedabad, Gujarat-380015, India; (M) 91-9825074864; E-mail: shailesh@iimahd.ernet.in.

${ }^{*}$ Corresponding author
} 
Many researchers show that a sudden stop or a sudden withdrawal is followed by large capital inflow in the form of Foreign Portfolio Flows. The concept of "sudden stop" was first coined by and later Calvo (1998) gave an analytical framework for examining the impact of a sudden and largely unexpected cut-back in foreign capital inflows to emerging economies. Calvo (2009) pointed out that India might be going through a "sudden stop" episode with the onset of the global crisis. In India important peaks were seen in May 2006 and January 2008; correspondingly, decline was witnessed after 3 to 6 months of these peaks, which confirms the episode of a sudden stop. The first shock of the global crisis on India was felt in the stock market in January 2008. This came through the reversal of inflows from Foreign Institutional Investors (FIIs) into the country. At the end of March 2008, India's foreign exchange reserves, at $\$ 309.7$ billion, provided a cover of $140 \%$ to total external debt. Capital flight in the form of "Hot money" (Stiglitz, 1999) drags the economy to adverse effects, especially during economic downturns in countries with small "absorptive capacity" (Prassad et al., 2003) and weak investor protection (Lemmon \&Lins, 2003).

Chakrabarti (2001) and tried to analyse FII flows to India and their relationship with other economic variables. They majorly detected that the FII net inflows are more likely to get affected by security returns than be the cause of equity market returns. Gordon \& Gupta (2003), using multivariate regression model, uncovered significant negative relation between monthly flows and lagged returns. Griffin, Nardari, \& Stulz(2002) found that foreign flows are significant predictors of returns for Korea, Thailand, Taiwan and India, indicating that foreign investors are buying before market index increases. Ananthanarayanan, Krishnamurti, \& Sen(2005) study the inter-relationship between Fll flows and domestic market returns. Their results are consistent with the base-broadening hypothesis. Ahmad, Ashraf, \& Ahmed (2005) and Kumar (2009) reveal that the Flls are influenced by the previous trading day returns, confirming the adoption of positive feedback strategy by them. All the above mentioned studies testify the relationship of Foreign Institutional Investment Flows with Indian Capital Market, whether it is a cause or an effect.

Albeit there is an increase in turnover of over all capital market of India, during 2011-12, the turnover of derivatives market exceeded the all-India cash market turnover by over 11 times ( as per the data provided by SEBI). In the derivatives segment, Institutional Investors particularly foreign investors play a major role as their investment in rupee terms is much higher than that of the domestic Institutional Investors. When some new information arrives, the actions of speculators swiftly feed their information into the derivatives market causing changes in the prices of derivatives. Therefore these markets indicate what is likely to happen and thus assist in better price discovery. The empirical research carried out by Chan, Chan, \& Karolyi(1991), Antoniou \& Holmes (1995), Choudhry (1997), Pericil\&Koutmos (1997), Bollen (1998), Abhayankar (1998), Gulen\& Mayhew (1999), McKenzie, Brailsford, \& Faff (2001), Gupta (2002), Thenmozhi (2002), Shenbagaraman (2003), Hetamsaria (2003) and Mukherjee \&Mishra (2006) also suggested that derivative trading might affect the underlying spot market and there is a lead lag relationship between the derivatives market and underlying spot market. No study has yet been contemplated to forecast the Fll flows using Auto Regressive Integrated Moving Average (ARIMA) modelling except the study of Sudalaimuthu\&Anbukarasi (2011). They tried to forecast the Fll flow on monthly basis using monthly data. Though the ARIMA model was introduced in 1994, it is being widely used across various disciplines for forecasting, e.g., to detect faults in the railway system, forecast stock prices, examine market efficiency, forecast short-term load in electric power system operation and planning, predict hourly electricity prices, model long-range dependant Internet traffic, for Short-time traffic flow prediction, forecast daily metro passenger flows, forecast spot prices in bulk shipping, forecast Chinese mobile user, examine the association between alcohol excise tax rates and alcohol-related traffic accidents, simulate the rain attenuation time series, predict air pollution PM2.5, detect and classify cancerous tumour etc. ${ }^{4}$. This study will try to forecast the daily flows of FII in Indian capital market, both aggregate/overall flows towards India and towards derivatives segment, particularly Futures.

The paper is organized as follows: Section 2 summarizes the data, sample period and the methodology used for modelling Foreign Institutional Investment flows. Section 3 discusses empirical results of the study. Section 4 summarizes the findings and Section 5 brings out the conclusion and discussion on the study.

${ }^{4}$ ReferMárquez, Pedregal\& Roberts (2015), Shan, Dai, Zhao,\& Liu (2015), Ariyo, Adewumi,\& Ayo (2014), Aruga\& Cook (2014), Cho, Hwang,\& Chen (1995), Fan, Mao, \& Chen (2007), El Hag \& Sharif (2007), Chen, Hu, Meng, \& Zhang (2011), Dong, Jia, Sun, Li, \& Qin (2009), Hai-yan (2010), Geomelos, Xideas, \& McMillan (2014), Ye (2010), Saar (2015), Yang, Li, Zhao, \& Zhang (2013), Wang \&Guo (2009), Kumar, Kumari, Ranjan, \&Vaish (2014). 


\section{Data and Methodology}

\section{Period of Study}

The data set comprises a daily flow of FII to India viz. Aggregate Inflow, Outflow and Netflow and daily positions of FII in Derivatives market, especially Long Position in futures, Short Position in futures and Futures Open Interest, for the period ranging from $1^{\text {st }}$ January, 2004 to $30^{\text {th }}$ September, 2012. The data were taken from the official website of the Security and Exchange Board of India. These data comprise, on the one hand, the period of Global Crisis and Eurozone Crisis and, on the other hand, the period of 2007, when Indian capital market (NIFTY- the benchmark index) touched its highest level. Both situations in turn cover the extreme values, so there is no need to assume that the market conditions remain unchanged or constant.

\section{Sample}

The sample consists of 2118 observations each for daily closing price of NIFTY, daily FII flows viz. Inflow, Outflow, Netflow, Long position in Futures market, Short position in Futures market and Open Interest. Derivatives trading commenced in India in June 2000 after SEBI granted the final approval with effect from May 2001. During the initial two years the derivatives market was in its infancy and investors were getting familiar with the new instruments, therefore data were collected from $1^{\text {st }}$ January, 2004.

\section{Methodology}

The first step of time series analysis is considered as checking the stationarity of the series. Stationarity is examined using Autocorrelation function and correlogram and unit root test.

The ACF at lag $k$ is defined as:

$$
\rho_{k}=\frac{\gamma_{k}}{\gamma_{0}}=\frac{\text { covariance at lag } k}{\text { variance }}
$$

The unit root test for stationarity can be represented as Augmented Dickey Fuller $(1979,1981)$ Regression and Phillips-Perron (1988) Regression. They are as follow:

1) Augmented Dickey Fuller Test

$$
\left.\Delta Y_{t}=B_{1}+B_{2} t+\delta Y_{t-1}+\sum_{i=1}^{m} \alpha_{i} \Delta Y_{t-i}+\varepsilon_{t}\right)
$$

2) Phillips-Perron Test

$$
Y_{t}=\alpha+\delta Y_{t-1}+\vartheta_{t}
$$

where the null hypothesis is that $\delta$, the coefficient of $Y_{t-1}$ is zero. This is called the unit root hypothesis. The acceptance of null hypothesis implies nonstationarity. The ADF test adjusts the DF to take care of a possible serial correlation in the error terms by adding the lagged difference terms of the regressand. Phillips and Perron use nonparametric statistical methods to take care of the serial correlation in the error terms without adding lagged difference terms. The PP test tends to be more robust to a wide range of serial correlation and time dependent heteroscedasticity.

The time series could be either a difference stationary process or a trend stationary process. All the time series which represent the FII flow show a significant trend and lead to a detrending process, that is, before analysis, it is necessary to remove the deterministic trend. This has been accomplished by estimating the following regression:

$$
Y_{t}=A_{1}+A_{2} t+v_{t}
$$


where $t$ is the trend variable and $v_{t}$ is the error term with usual properties. After running this regression, we obtain;

$$
\left.\hat{v}=Y_{t}-a_{1}-a_{2} t\right)
$$

The estimated error term now represents the detrended $Y$ time series, that is, $Y$ with the trend removed.

Box and Jenkinsput forward a new generation forecasting tool, popularly known as the Box-Jenkins (BJ) methodology, but technically known as the ARIMA methodology. The BJ-type time series models allow $Y_{t}$ to be explained by past, or lagged, values of $Y$ itself and stochastic error terms, under the philosophy let the data speak for themselves. The BJ methodology is based on the assumption that the time series under study is stationary. If a time series is stationary, we can model it in a variety of ways.

$Y_{t}$ is an autoregressive model of order $p$ or $\mathbf{A R}(\boldsymbol{p})$ process in following difference equation or model (6),

$$
Y_{t}=a_{0}+\sum_{i=1}^{p} a_{i} Y_{t-i}+\varepsilon_{t}
$$

Model (7) is known as Moving Average of order $q$ or MA(q) model, where $Y_{t}$ is expressed as weighted or moving average of the current and past white noise error terms.

$$
Y_{t}=a_{0}+\sum_{i=1}^{q} \beta_{i} \varepsilon_{t-i}
$$

By combining AR and MA models, one can get the ARMA $(p, q)$ model, with $p$ autoregressive terms and $q$ moving average terms.

$$
Y_{t}=a_{0}+Y_{t}=a_{0}+\sum_{i=1}^{p} a_{i} Y_{t-i}+\sum_{i=1}^{q} \beta_{i} \varepsilon_{t-i}
$$

If for making the time series differencing is needed, the process becomes integrated and is generally known as Auto Regressive Integrated Moving Average or $\operatorname{ARIMA}(\boldsymbol{p}, \boldsymbol{d}, \boldsymbol{q})$ model, where $d$ denotes the number of times a time series has to be differenced to make it stationary. In case of the considered FII series, they all are stationary at level only, therefore they can be termed as $I(0)$ and there is an absence of $d$ term. The BJ methodology follows the four-step procedure, viz. Identification, Estimation, Diagnostic checking and Forecasting, out of which up to a third stage the BJ methodology is an iterative process.

\section{Empirical Analysis}

For the convenience purpose all Fll series have been identified using the following abbreviations.

\section{List of Abbreviations}

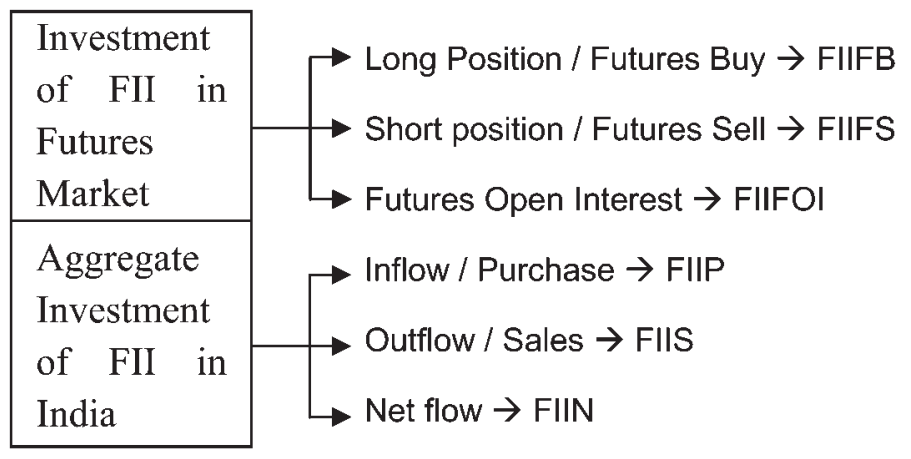


Table 1: Unit Root Test for Daily Trends of FII in Futures Market and Aggregate Daily FII Flows

\begin{tabular}{|l|r|r|r|r|r|r|}
\hline \multicolumn{7}{|c|}{ Augmented Dickey-Fuller test statistic } \\
\hline Variable & \multicolumn{1}{c}{ FIIFB } & \multicolumn{1}{c|}{ FIIFS } & \multicolumn{1}{c|}{ FIIFOI } & \multicolumn{1}{c|}{ FIIP } & \multicolumn{1}{c|}{ FIIS } & \multicolumn{1}{c|}{ FIIN } \\
\hline t-Statistic & -3.934 & -3.907 & -4.471 & -8.244 & -6.286 & -12.727 \\
\hline Slope Coefficient & $(0.011)$ & $(0.012)$ & $(0.002)$ & $(0.000)$ & $(-0.017)$ & $(0.000)$ \\
\hline & -0.185 & -0.135 & -0.027 & -0.177 & -0.122 & -0.364 \\
\hline Intercept & $(0.000)$ & $(0.000)$ & $(0.000)$ & $(0.000)$ & $(0.000)$ & $(0.000)$ \\
\hline & 17.134 & 12.149 & 16.245 & -0.202 & 3.072 & -1.466 \\
\hline Trend Coefficient & $(0.805)$ & $(0.793)$ & $(0.759)$ & $(0.996)$ & $(0.932)$ & $(0.965)$ \\
\hline & -0.015 & -0.011 & -0.014 & 0.002 & -0.002 & 0.002 \\
\hline & $(0.786)$ & $(0.764)$ & $(0.759)$ & $(0.952)$ & $(0.946)$ & $(0.938)$ \\
\hline Variable & & Phillips-Perron test statistic & & \multicolumn{1}{c|}{} \\
\hline Adj. t-Statistic & FIIFB & FIIFS & FIIFOI & FIIP & FIIS & FIIN \\
\hline & -28.342 & -19.937 & -6.587 & -23.050 & -20.215 & -29.567 \\
\hline Slope Coefficient & $(0.000)$ & $(0.000)$ & $(-0.002)$ & $(0.000)$ & $(0.000)$ & $(0.000)$ \\
\hline & -0.551 & -0.317 & -0.040 & -0.401 & -0.323 & -0.586 \\
\hline Intercept & $(0.000)$ & $(0.000)$ & $(0.000)$ & $(0.000)$ & $(0.000)$ & $(0.000)$ \\
\hline & -0.644 & -1.273 & 13.095 & 1.778 & 2.387 & -0.662 \\
\hline Trend Coefficient & $(0.993)$ & $(0.979)$ & $(0.823)$ & $(0.970)$ & $(0.9500$ & $(0.985)$ \\
\hline & 0.002 & 0.002 & -0.013 & -0.001 & -0.002 & 0.001 \\
\hline & $(0.979)$ & $(0.951)$ & $(0.792)$ & $(0.978)$ & $(0.951)$ & $(0.979)$ \\
\hline
\end{tabular}

Note: Figures in parenthesis are Mackinnon one-sided p-values. Estimation procedure follows Ordinary Least Square (OLS) method. The $t$ - statistics of the slope coefficient follows the $\mathrm{T}$ (tau) statistics. Critical values are -3.4119 and 3.1277 at $5 \%$ and $10 \%$ significance level respectively.

The descriptive statistics of Trends of Daily FII in Futures market in terms of Buy (long) position, Sell (short) position and Open Interest and Daily aggregate investment of Flls in stock market in terms of Inflow, Outflow and Netflow reject the hypothesis of normal distribution for all the series. Autocorrelation coefficients are statistically significant as they fall outside the critical interval. This shows the presence of autocorrelation for all the considered series.

For confirming the serial correlation or autocorrelation Unit root test is applied. Table 1 represents the result of Augmented Dickey Fuller Test and Phillips-Perron Test which checks the presence of unit root for considered series. The absolute values of t-statistics or adjusted t-statistics (in case of Phillip-Perron Test) exceed the critical value 3.4119 at $5 \%$ level and are highly significant. The $\delta$ - value which is represented by slope coefficients is also negative for all the series, therefore the null hypothesis for both tests is rejected and stationarity of all the series is confirmed. ${ }^{5}$ 
The first step in BJ methodology is identification. The chief tools in identification of $p$ and $q$ are the autocorrelation function (ACF), the partial autocorrelation function (PACF), and the resulting correlograms, which are simply the plots of ACFs and PACFs against the lag length. Partial autocorrelation is the correlation between $Y_{t}$ and $Y_{t-k}$ after removing the effect of the intermediate $Y^{\prime}$ 's.

Table 2 represents the autocorrelation function (ACF) and partial autocorrelation function (PACF) along with the correlogram for three series, namely, Bought Position of FII, Short position of FII and Open Interest of FII in futures market.

The ACF statistics at lag 1-4 seem statistically different from zero for FIIFB and FIIFS and almost all other lags are insignificant as they fall within the asymptotic bounds $2 T^{0.5}( \pm 0.0434)$. The PACF with spikes 1 and 2 for FIIFB and 1 and 3 for FIIFS seem statistically significant, but the rest are not as they fall within the asymptotic bounds. Moreover, as the exponential decay can be seen in ACF, and PACF is showing spikes up to lag 2 for FIIFB, it suggests AR(2) or AR(1) processes. FIIFS shows exponential decay in only ACF and significant spikes at lag 1 and 3 for PACF, which points towards the $\operatorname{AR}(1)$ or $A R(1,3)$ processes. For FIIFOI, the ACF up to lag 15 seems highly significant, as at lag 15 also autocorrelation coefficient is 0.807 and most of the lags of PACF are insignificant except at lag 1-3, suggesting either the existence of AR(3) model or a combination of AR and MA processes, i.e., ARMA model, which requires few iterations.

In table 3, correlogram of daily gross purchase (FIIP), gross sales (FIIS) and Net flow (FIIN) of FII in Indian Capital Market have been shown. If the plots are observed minutely, it seems that higher order AR terms or again combination of ARMA process might be present.

After identifying approximate $p$ and $q$ values, the next stage is to estimate the parameters of the autoregressive and moving average terms included in the model. For the best suited model, considered AR and MA terms (in particular model) should be statistically significant at $5 \%$ level of significance. Apart from that, all the R-squared value should be highest and the values of Akaike Information Criterion (AIC) ${ }^{6}$ and Schwarz Bayesian Criterion (SBC) ${ }^{7}$ should be the least. Therefore estimation of best model adopts a trial and error approach.

${ }^{6}$ Like the adjusted R-squared, the AIC criterion adds somewhat harsher penalty for adding more variables to the model; AIC is defined as follows:

$$
\ln A I C=\frac{2 k}{n}+\ln \left(\frac{R S S}{n}\right)
$$

${ }^{7} \mathrm{SBC}$ is an alternative to AIC criterion, which in its long form can be expressed as:

$$
\ln S B C=\frac{k}{n} \ln n+\ln \left(\frac{R S S}{n}\right)
$$

Here the penalty factor $[(k / n) \ln n]$ is harsher than that of AIC. 
Table 2: ACF and PACF with Resultant Correlogram for Daily Trends of FII in Futures Market

\begin{tabular}{|c|c|c|c|c|c|c|c|c|c|c|c|c|c|c|c|}
\hline \multirow[b]{2}{*}{ Lag } & \multicolumn{5}{|c|}{ FIIFB } & \multicolumn{5}{|c|}{ FIIFS } & \multicolumn{5}{|c|}{ FIIFOI } \\
\hline & $\begin{array}{l}\text { Autocorrelati } \\
\text { on }\end{array}$ & $\begin{array}{c}\text { Partial } \\
\text { Correlation }\end{array}$ & ACF & PACF & Q-Stat & $\begin{array}{c}\text { Autocorrelati } \\
\text { on }\end{array}$ & $\begin{array}{c}\text { Partial } \\
\text { Correlation }\end{array}$ & ACF & PACF & Q-Stat & $\begin{array}{l}\text { Autocorrelati } \\
\text { on }\end{array}$ & $\begin{array}{c}\text { Partial } \\
\text { Correlation }\end{array}$ & ACF & PACF & Q-Stat \\
\hline 1 & $\left.\right|^{* \star *} \mid$ & $\mid$ *** $\mid$ & 0.45 & 0.45 & 426.58 & 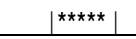 & $|* * \star \star \star|$ & 0.68 & 0.68 & 985.70 & 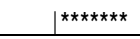 & 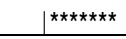 & 0.96 & 0.96 & 1954.30 \\
\hline 2 & $\left.\right|^{* *}$ & $\perp^{*}$ & 0.29 & 0.12 & 610.57 & $|* * *|$ & $\perp$ & 0.44 & -0.04 & 1401.70 & $\mid * \star \star * \star \star *$ & $\left.\right|^{*}$ & 0.94 & 0.21 & 3817.90 \\
\hline 3 & $\perp^{*}$ & $\perp$ & 0.15 & -0.02 & 660.37 & $\perp^{* *} \mid$ & * & 0.24 & -0.08 & 1528.50 & 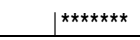 & $\perp^{*} \mid$ & 0.92 & 0.09 & 5608.80 \\
\hline 4 & $\perp^{*}$ & 1 & 0.11 & 0.03 & 685.44 & $\perp^{*}$ & $\mid$ & 0.14 & 0.02 & 1568.20 & 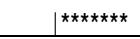 & | & 0.90 & 0.07 & 7341.90 \\
\hline 5 & 1 & 1 & 0.07 & 0.01 & 696.62 & | & $\mid$ & 0.07 & -0.01 & 1578.40 & $|* * \star * * *|$ & $\perp$ & 0.89 & 0.05 & 9024.10 \\
\hline 6 & | & | & 0.05 & 0.01 & 702.56 & | & | & 0.03 & -0.01 & 1580.60 & 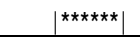 & | & 0.88 & 0.02 & 10655.00 \\
\hline 7 & 1 & & 0.01 & -0.03 & 702.85 & $\perp$ & $\mid$ & -0.01 & -0.03 & 1580.60 & 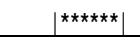 & $\perp$ & 0.87 & 0.05 & 12249.00 \\
\hline 8 & | & | & 0.01 & 0.00 & 702.90 & $\mid$ & 1 & -0.02 & 0.00 & 1581.50 & $\mid$ |*****| & $\mid$ & 0.85 & 0.00 & 13796.00 \\
\hline 9 & 1 & $\mid$ & 0.01 & 0.02 & 703.16 & 1 & 1 & -0.03 & -0.01 & 1583.20 & 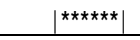 & 1 & 0.84 & 0.04 & 15309.00 \\
\hline 10 & 1 & 1 & -0.01 & -0.03 & 703.48 & $\mid$ & 1 & -0.03 & 0.00 & 1584.60 & $\mid$ ******| $\mid$ & $\mid$ & 0.83 & 0.03 & 16790.00 \\
\hline 11 & $\perp$ & | & -0.03 & -0.02 & 705.19 & $\mid$ & $\perp$ & -0.04 & -0.03 & 1587.10 & 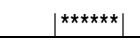 & $\perp$ & 0.83 & 0.03 & 18244.00 \\
\hline 12 & 1 & 1 & -0.01 & 0.03 & 705.27 & $\mid$ & $\perp$ & -0.01 & 0.04 & 1587.60 & 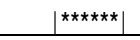 & $\perp$ & 0.82 & 0.05 & 19679.00 \\
\hline 13 & 1 & 1 & -0.01 & 0.00 & 705.34 & & 1 & 0.00 & 0.00 & 1587.60 & $\mid$ ******| & 1 & 0.81 & 0.02 & 21093.00 \\
\hline 14 & 1 & 1 & 0.03 & 0.04 & 707.08 & & & 0.02 & 0.04 & 1588.80 & $\mid$ ***** $\mid$ & 1 & 0.81 & 0.05 & 22493.00 \\
\hline 15 & $\mid$ & 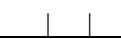 & 0.05 & 0.04 & 712.23 & 1 & $\mid$ & 0.07 & 0.06 & 1598.00 & $|\star * \star * * *|$ & & 0.81 & 0.05 & 23885.00 \\
\hline
\end{tabular}

Table 3: ACF and PACF with Resultant Correlogram for Aggregate Daily FII Flows

\begin{tabular}{|c|c|c|c|c|c|c|c|c|c|c|c|c|c|c|c|}
\hline \multirow[b]{2}{*}{ Lag } & \multicolumn{5}{|c|}{ FIIP } & \multicolumn{5}{|c|}{ FIIS } & \multicolumn{5}{|c|}{ FIIN } \\
\hline & $\begin{array}{l}\text { Autocorrelati } \\
\text { on }\end{array}$ & $\begin{array}{c}\text { Partial } \\
\text { Correlation }\end{array}$ & ACF & PACF & Q-Stat & $\begin{array}{l}\text { Autocorrelat } \\
\text { ion }\end{array}$ & $\begin{array}{c}\text { Partial } \\
\text { Correlation }\end{array}$ & ACF & PACF & Q-Stat & $\begin{array}{l}\text { Autocorrelat } \\
\text { ion }\end{array}$ & $\begin{array}{c}\text { Partial } \\
\text { Correlation }\end{array}$ & ACF & PACF & Q-Stat \\
\hline 1 & $\left.\right|^{* * * *} \mid$ & $|* * * *|$ & 0.599 & 0.599 & 761.71 & $\mid * \star \star \star \star *$ & $|* * * \star *|$ & 0.677 & 0.677 & 972.12 & $\left.\right|^{* * *}$ & $\left.\right|^{* * *} \mid$ & 0.414 & 0.414 & 363.88 \\
\hline 2 & $\perp^{* * *} \mid$ & $\perp^{*}$ & 0.481 & 0.19 & 1252.9 & $\perp^{* * * *} \mid$ & $\perp^{*}$ & 0.57 & 0.208 & 1663.7 & $\left.\right|^{* *}$ & $\perp^{*}$ & 0.285 & 0.137 & 536.41 \\
\hline 3 & $\left.\right|^{* * *} \mid$ & $\left.\right|^{*}$ & 0.445 & 0.159 & 1674.2 & $\left.\right|^{* \star * *} \mid$ & $\left.\right|^{*}$ & 0.52 & 0.143 & 2239.3 & $\left.\right|^{* \star}$ & $\left.\right|^{*}$ & 0.271 & 0.138 & 692.24 \\
\hline 4 & $\left.\right|^{* * *} \mid$ & $1^{*}$ & 0.464 & 0.185 & 2131.4 & $\left.\right|^{* * * *} \mid$ & $\left.\right|^{*}$ & 0.531 & 0.189 & 2839.1 & $\left.\right|^{* *}$ & $\left.\right|^{*}$ & 0.237 & 0.079 & 811.63 \\
\hline 5 & $\left.\right|^{* * *} \mid$ & $\left.\right|^{*}$ & 0.456 & 0.122 & 2574.2 & $\left.\right|^{* * * *} \mid$ & $\perp^{*}$ & 0.521 & 0.114 & 3415.8 & $\left.\right|^{* *}$ & $\left.\right|^{*}$ & 0.233 & 0.088 & 927.61 \\
\hline 6 & $\perp^{* * *} \mid$ & $\perp^{*}$ & 0.438 & 0.087 & 2982 & $\perp^{* \star * *} \mid$ & $\perp^{*}$ & 0.502 & 0.079 & 3953 & $\perp^{*}$ & $\perp$ & 0.211 & 0.051 & 1022.1 \\
\hline 7 & $\perp^{* * *} \mid$ & $\perp$ & 0.394 & 0.023 & 3312.7 & $\perp^{* * *} \mid$ & $\perp$ & 0.471 & 0.037 & 4425.5 & $\perp^{*}$ & $\perp$ & 0.162 & 0.002 & 1077.7 \\
\hline 8 & $|* * *|$ & $\perp$ & 0.391 & 0.061 & 3638.1 & $\left.\right|^{* * *} \mid$ & 1 & 0.46 & 0.054 & 4876.3 & $\perp^{*}$ & 1 & 0.155 & 0.026 & 1128.6 \\
\hline 9 & $\left.\right|^{* * *} \mid$ & $\perp$ & 0.384 & 0.044 & 3953 & $\left.\right|^{* * *} \mid$ & $1^{*}$ & 0.47 & 0.083 & 5346.3 & $1^{*}$ & 1 & 0.136 & 0.009 & 1167.9 \\
\hline 10 & $\perp^{* * *}$ & $\perp^{*}$ & 0.402 & 0.081 & 4297.2 & $\perp^{* * *} \mid$ & $\perp$ & 0.467 & 0.054 & 5811 & $\perp^{*}$ & $\perp^{*}$ & 0.181 & 0.085 & 1237.7 \\
\hline 11 & $\left.\right|^{* \star *} \mid$ & 1 & 0.374 & 0.014 & 4595.4 & $\left.\right|^{* * *} \mid$ & $\perp$ & 0.444 & 0.016 & 6232.5 & $\perp^{*}$ & 1 & 0.138 & -0.005 & 1278.2 \\
\hline 12 & $\left.\right|^{* * *} \mid$ & $\perp$ & 0.375 & 0.053 & 4895.1 & $\left.\right|^{* * *} \mid$ & $\perp$ & 0.438 & 0.042 & 6642 & $1^{*}$ & $\perp$ & 0.122 & 0.012 & 1310.1 \\
\hline 13 & $\left.\right|^{* \star *} \mid$ & I & 0.368 & 0.035 & 5183.6 & $\left.\right|^{* \star *} \mid$ & 1 & 0.438 & 0.043 & 7051 & $\left.\right|^{*}$ & 1 & 0.132 & 0.03 & 1347.5 \\
\hline 14 & $\perp^{* * *} \mid$ & $\perp$ & 0.358 & 0.019 & 5458.1 & $\perp^{* * *} \mid$ & $\perp$ & 0.436 & 0.034 & 7457.2 & $\perp^{*}$ & $\perp$ & 0.1 & -0.014 & 1368.8 \\
\hline 15 & $\perp^{* *} \mid$ & $\perp$ & 0.348 & 0.017 & 5716.6 & $\left.\right|^{* * *} \mid$ & 1 & 0.419 & 0.005 & 7832.1 & $\perp^{*}$ & $\perp$ & 0.083 & -0.013 & 1383.5 \\
\hline
\end{tabular}


Table 4: Estimates of Parameters of ARMA Models for FIIFB, FIIFS, FIIFOI, FIIP, FIIS and FIIN

\begin{tabular}{|c|c|c|c|c|c|c|c|c|}
\hline & $\begin{array}{l}\text { Model } \\
\text { Type }\end{array}$ & $\begin{array}{c}\text { Variabl } \\
e\end{array}$ & Coefficient & t-Stat & Prob. & $\begin{array}{c}\text { Adj } \\
\text { R-squared }\end{array}$ & AIC & SBC \\
\hline \multirow{3}{*}{ FIIFB } & \multirow{3}{*}{$\operatorname{AR}(2)$} & C & 2.8381 & 0.0388 & 0.969 & \multirow{3}{*}{0.2115} & \multirow{3}{*}{17.638} & \multirow{3}{*}{17.646} \\
\hline & & $A R(1)$ & 0.3964 & 18.350 & 0.000 & & & \\
\hline & & $\operatorname{AR}(2)$ & 0.1175 & 5.4363 & 0.000 & & & \\
\hline \multirow{3}{*}{ FIIFS } & \multirow{3}{*}{$\operatorname{AR}(1,3)$} & $\mathrm{C}$ & 3.128 & 0.047 & 0.9625 & \multirow{3}{*}{0.4687} & \multirow{3}{*}{16.832} & \multirow{3}{*}{16.840} \\
\hline & & $\operatorname{AR}(1)$ & 0.7142 & 40.381 & 0.000 & & & \\
\hline & & $\mathrm{AR}(3)$ & -0.0711 & -4.0189 & 0.0001 & & & \\
\hline \multirow{5}{*}{ FIIFOI } & \multirow{5}{*}{$\operatorname{ARMA}(2,2)$} & $C$ & 79.5513 & 0.0369 & 0.9706 & \multirow{5}{*}{0.9264} & \multirow{5}{*}{17.182} & \multirow{5}{*}{17.196} \\
\hline & & $\mathrm{AR}(1)$ & 1.8040 & 49.190 & 0.0000 & & & \\
\hline & & $\operatorname{AR}(2)$ & -0.8047 & -22.114 & 0.0000 & & & \\
\hline & & $M A(1)$ & -1.0830 & -24.417 & 0.0000 & & & \\
\hline & & $\mathrm{MA}(2)$ & 0.1416 & 4.5079 & 0.0000 & & & \\
\hline \multirow{6}{*}{ FIIP } & \multirow{6}{*}{$\begin{array}{c}\text { ARMA } \\
(1,2,4,6), 1)\end{array}$} & $C$ & 33.7388 & 0.1432 & 0.8861 & \multirow{6}{*}{0.4394} & \multirow{6}{*}{16.680} & \multirow{6}{*}{16.696} \\
\hline & & $\mathrm{AR}(1)$ & 1.2880 & 38.568 & 0.0000 & & & \\
\hline & & $\operatorname{AR}(2)$ & -0.2918 & -9.9164 & 0.0000 & & & \\
\hline & & $\mathrm{AR}(4)$ & 0.0505 & 2.4473 & 0.0145 & & & \\
\hline & & $A R(6)$ & -0.0547 & -3.1820 & 0.0015 & & & \\
\hline & & $M A(1)$ & -0.9152 & -36.443 & 0.0000 & & & \\
\hline \multirow{5}{*}{ FIIS } & \multirow{5}{*}{$\begin{array}{c}\text { ARMA } \\
(1,2,6), 1)\end{array}$} & C & 3.1341 & 0.0097 & 0.9923 & \multirow{5}{*}{0.5276} & \multirow{5}{*}{16.264} & \multirow{5}{*}{16.278} \\
\hline & & $\mathrm{AR}(1)$ & 1.3701 & 53.524 & 0.0000 & & & \\
\hline & & $\operatorname{AR}(2)$ & -0.3329 & -13.153 & 0.0000 & & & \\
\hline & & $\operatorname{AR}(6)$ & -0.0401 & -3.8489 & 0.0001 & & & \\
\hline & & $M A(1)$ & -0.9493 & -66.953 & 0.0000 & & & \\
\hline \multirow{4}{*}{ FIIN } & \multirow{4}{*}{$\begin{array}{c}\text { ARMA } \\
(2,1)\end{array}$} & $\mathrm{C}$ & 4.0054 & 0.0690 & 0.9450 & \multirow{4}{*}{0.2157} & \multirow{4}{*}{16.112} & \multirow{4}{*}{16.123} \\
\hline & & $A R(1)$ & 1.0988 & 24.836 & 0.0000 & & & \\
\hline & & $\operatorname{AR}(2)$ & -0.1589 & -4.9016 & 0.0000 & & & \\
\hline & & $M A(1)$ & -0.7899 & -21.604 & 0.0000 & & & \\
\hline
\end{tabular}

Table 4 shows the results of estimated models for FIIFB, FIIFS, FIIFOI, FIIP, FIIS and FIIN respectively, based on clues absorbed from correlogram. For each of the series the model is chosen over other estimated model using the trial and error approach based on AIC, BIC and adjusted R-squared.

Table 5: Breusch-Godfrey Serial Correlation LM Test for Estimated models

\begin{tabular}{|l|c|c|r|r|r|r|}
\hline & $\begin{array}{l}\text { FIIFB- } \\
\text { AR(2) }\end{array}$ & $\begin{array}{l}\text { FIIFS- } \\
\text { AR(1,3) }\end{array}$ & $\begin{array}{l}\text { FIIFOI- } \\
\text { ARMA(2,2) }\end{array}$ & $\begin{array}{l}\text { FIIP- } \\
\text { ARMA((1,2,4,6),1) }\end{array}$ & $\begin{array}{l}\text { FIIS- } \\
\text { ARMA((1,2,6), 1) }\end{array}$ & $\begin{array}{l}\text { FIIN- } \\
\text { ARMA(2,1) }\end{array}$ \\
\hline F-stat & 0.719 & 0.625 & 0.928 & 0.806 & 1.105 & 1.421 \\
\hline Prob. & 0.768 & 0.856 & 0.532 & 0.673 & 0.346 & 0.128 \\
\hline Obs. $\mathbf{R}^{2}$ & 10.819 & 9.419 & 13.954 & 12.135 & 16.598 & 21.294 \\
\hline$\chi^{2}$-Prob. & 0.765 & 0.855 & 0.529 & 0.669 & 0.343 & 0.128 \\
\hline
\end{tabular}


Table 5 represents the Breusch-Godfrey Serial Correlation LM Test for Estimated models as a diagnostic tool for appropriateness of a model. The null hypothesis of the LM test is that there is no serial correlation up to lag order $p$, where $p$ is a pre-specified integer. The $F$-statistic is an omitted variable test for the joint significance of all lagged residuals. The Obs. $R$-squared statistic is the Breusch- Godfrey LM test statistic. Both statistics of the serial correlation LM test for estimated equation with 15 lags fail to reject the null hypothesis of no serial correlation for all considered models.
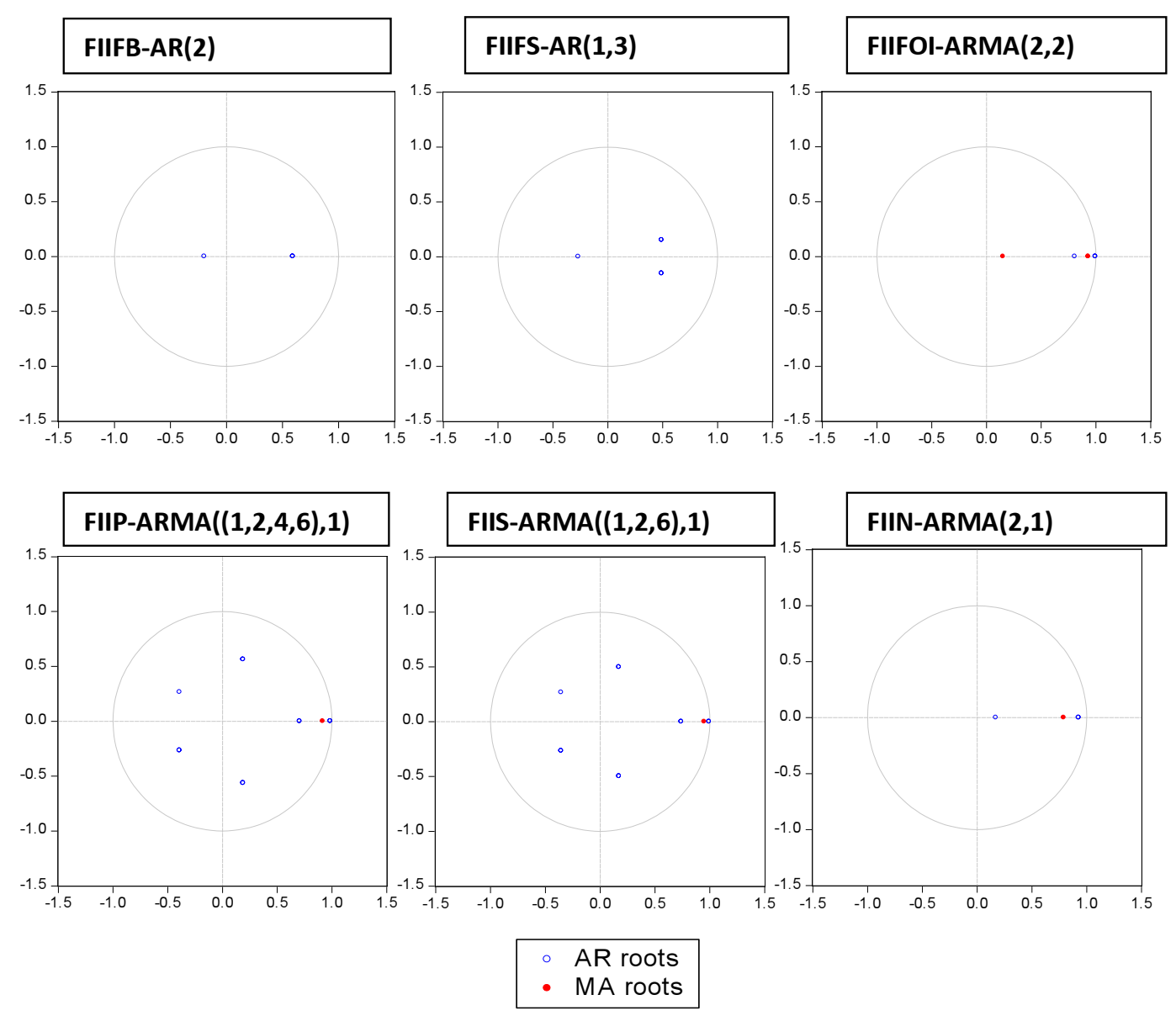

Figure 6: Inverse Roots of Estimated polynomials

The ACF, PACF and Ljung-Box Q Statistics have been computed for the residuals so obtained from the estimated models. It can be very easily inferred from Table 6 that all ACF and PACF are statistically significant suggesting the full absorption of available information in the model.

After identifying the processes, as per the third step of BJ methodology diagnostic checking was undertaken through ACF, PACF, Ljung-Box Q Statistics, Serial-correlation LM test and by plotting inverse roots of estimated polynomial, which are shown through Table 12 and 13 and Figure 1.

If the estimated ARMA process is (covariance) stationary, then all AR roots should lie inside the unit circle and if the estimated ARMA process is invertible, then all MA roots should lie inside the unit circle. Figure 1 strengthens the fact about proper specification of estimated model using inverse root of polynomial, as all the $A R$ and MA roots are falling inside the unity circle for all specified models. These charts are in the form of Argand diagram. They allow for the fact that some roots may be complex numbers of the form $z=(x+/-$ iy), where the imaginary number, $i$, satisfies $i^{2}=-1$. The $X$-axis in those diagrams plots the real $(x)$ part of $z$, and the Y-axis plots the imaginary $(y)$ part of $z$. So, if a root is real, it will lie on the horizontal axis; but if it is complex, it will be located at the point $(x, y)$. 
Table 7: Diagnostic Checking through ACF, PACF and Ljung-Box Q Statistics for estimated Models

\begin{tabular}{|c|c|c|c|c|c|c|c|c|c|c|c|c|}
\hline \multirow{2}{*}{ Lag } & \multicolumn{4}{|c|}{ FIIFB-AR(2) } & \multicolumn{4}{|c|}{ FIIFS-AR(1,3) } & \multicolumn{4}{|c|}{ FIIFOI-ARMA(2,2) } \\
\hline & ACF & PACF & Q-Stat & Prob & ACF & PACF & Q-Stat & Prob & ACF & PACF & Q-Stat & Prob \\
\hline 1 & 0.002 & 0.002 & 0.011 & & -0.006 & -0.006 & 0.070 & & 0.001 & 0.001 & 0.003 & \\
\hline 2 & 0.006 & 0.006 & 0.081 & & 0.010 & 0.010 & 0.303 & & -0.007 & -0.007 & 0.093 & \\
\hline 3 & -0.028 & -0.028 & 1.762 & 0.184 & -0.015 & -0.014 & 0.752 & 0.386 & -0.007 & -0.007 & 0.207 & \\
\hline 4 & 0.010 & 0.010 & 1.957 & 0.376 & 0.013 & 0.012 & 1.092 & 0.579 & 0.011 & 0.011 & 0.449 & \\
\hline 5 & 0.012 & 0.012 & 2.260 & 0.520 & 0.007 & 0.007 & 1.194 & 0.754 & 0.025 & 0.025 & 1.751 & 0.186 \\
\hline 6 & 0.024 & 0.023 & 3.490 & 0.479 & 0.022 & 0.022 & 2.248 & 0.690 & -0.010 & -0.010 & 1.971 & 0.373 \\
\hline 7 & -0.021 & -0.021 & 4.462 & 0.485 & -0.023 & -0.022 & 3.361 & 0.645 & 0.034 & 0.035 & 4.468 & 0.215 \\
\hline 8 & -0.009 & -0.009 & 4.647 & 0.590 & -0.008 & -0.008 & 3.490 & 0.745 & -0.018 & -0.018 & 5.170 & 0.270 \\
\hline 9 & 0.023 & 0.024 & 5.763 & 0.568 & -0.013 & -0.012 & 3.823 & 0.800 & -0.006 & -0.007 & 5.257 & 0.385 \\
\hline 10 & -0.011 & -0.012 & 6.002 & 0.647 & 0.014 & 0.012 & 4.216 & 0.837 & -0.017 & -0.017 & 5.880 & 0.437 \\
\hline 11 & -0.035 & -0.036 & 8.644 & 0.471 & -0.043 & -0.042 & 8.103 & 0.524 & -0.027 & -0.027 & 7.387 & 0.390 \\
\hline 12 & 0.004 & 0.005 & 8.672 & 0.563 & 0.016 & 0.015 & 8.637 & 0.567 & 0.005 & 0.003 & 7.440 & 0.490 \\
\hline 13 & -0.022 & -0.021 & 9.710 & 0.557 & -0.014 & -0.012 & 9.084 & 0.614 & -0.029 & -0.028 & 9.199 & 0.419 \\
\hline 14 & 0.008 & 0.005 & 9.839 & 0.630 & -0.002 & -0.004 & 9.092 & 0.695 & -0.023 & -0.024 & 10.339 & 0.411 \\
\hline 15 & -0.013 & -0.013 & 10.184 & 0.679 & 0.016 & 0.018 & 9.644 & 0.723 & -0.018 & -0.016 & 11.058 & 0.438 \\
\hline \multirow{2}{*}{ Lag } & \multicolumn{4}{|c|}{ FIIP-ARMA((1,2,4,6),1) } & \multicolumn{4}{|c|}{ FIIS-ARMA((1,2,6),1) } & \multicolumn{4}{|c|}{ FIIN-ARMA $(2,1)$} \\
\hline & ACF & PACF & Q-Stat & Prob & ACF & PACF & Q-Stat & Prob & ACF & PACF & Q-Stat & Prob \\
\hline 1 & -0.002 & -0.002 & 0.012 & & 0.001 & 0.001 & 0.001 & & 0.003 & 0.003 & 0.017 & \\
\hline 2 & 0.007 & 0.007 & 0.113 & & 0.007 & 0.007 & 0.095 & & -0.020 & -0.020 & 0.841 & \\
\hline 3 & -0.006 & -0.006 & 0.190 & & -0.051 & -0.051 & 5.693 & & 0.020 & 0.020 & 1.664 & \\
\hline 4 & 0.011 & 0.011 & 0.462 & & 0.022 & 0.022 & 6.715 & & -0.006 & -0.006 & 1.733 & 0.188 \\
\hline 5 & -0.017 & -0.017 & 1.073 & & 0.002 & 0.003 & 6.725 & 0.010 & 0.021 & 0.022 & 2.660 & 0.264 \\
\hline 6 & 0.030 & 0.030 & 2.999 & 0.083 & 0.028 & 0.026 & 8.448 & 0.015 & 0.018 & 0.017 & 3.339 & 0.342 \\
\hline 7 & -0.028 & -0.028 & 4.722 & 0.094 & -0.013 & -0.011 & 8.827 & 0.032 & -0.034 & -0.033 & 5.801 & 0.215 \\
\hline 8 & -0.001 & -0.002 & 4.727 & 0.193 & -0.016 & -0.016 & 9.353 & 0.053 & -0.013 & -0.013 & 6.172 & 0.290 \\
\hline 9 & -0.019 & -0.018 & 5.483 & 0.241 & 0.024 & 0.027 & 10.614 & 0.060 & -0.038 & -0.040 & 9.327 & 0.156 \\
\hline 10 & 0.044 & 0.043 & 9.601 & 0.087 & 0.035 & 0.033 & 13.183 & 0.040 & 0.058 & 0.059 & 16.448 & 0.021 \\
\hline 11 & -0.018 & -0.016 & 10.276 & 0.113 & -0.008 & -0.009 & 13.309 & 0.065 & -0.005 & -0.008 & 16.503 & 0.036 \\
\hline 12 & 0.013 & 0.010 & 10.620 & 0.156 & 0.001 & 0.003 & 13.311 & 0.102 & -0.011 & -0.006 & 16.751 & 0.053 \\
\hline 13 & 0.010 & 0.012 & 10.824 & 0.212 & 0.013 & 0.016 & 13.650 & 0.135 & 0.027 & 0.026 & 18.278 & 0.050 \\
\hline 14 & 0.003 & 0.001 & 10.849 & 0.286 & 0.026 & 0.024 & 15.085 & 0.129 & -0.012 & -0.011 & 18.581 & 0.069 \\
\hline 15 & -0.015 & -0.013 & 11.343 & 0.331 & -0.005 & -0.006 & 15.132 & 0.177 & -0.029 & -0.029 & 20.346 & 0.061 \\
\hline
\end{tabular}

\section{Findings}

Based on the analysis the following equations are estimated for different series of Fll flows, which can be used for forecasting future course.

1) FIIFB- Long (Bought) Position of FII in Futures Market- AR(2)

$$
F I I F B_{t}=0.3964 F I I F B_{t-1}+0.1175 F I I F B_{t-2}+\varepsilon_{t}
$$

2) FIIFS- Short (Sold) Position of FII in Futures Market- AR(1,3)

$$
\text { FIIFS }_{t}=0.7142 \text { FIIFS }_{t-1}-0.0711 \text { FIIFS }_{t-3}+\varepsilon_{t}
$$

3) FIIFOI- Open Interest of FII for Futures market- ARMA(2,2)

$$
\text { FIIFOI }_{t}=1.8040 \text { FIIFOI }_{t-1}-0.8047 \text { IIFOI }_{t-2}+\varepsilon_{t}-1.0830 \varepsilon_{t-1}+0.1461 \varepsilon_{t-2}
$$

4) FIIP- Aggregate Foreign Institutional Inflow-ARMA((1,2,4,6),1)

$$
F I I P_{t}=1.288 F I I P_{t-1}-0.2918 F I I P_{t-2}+0.0505 F I I P_{t-4}-0.0547 F I I P_{t-6}+\varepsilon_{t}-0.9152 \varepsilon_{t-1}
$$


5) FIIS- Aggregate Foreign Institutional Outflow-ARMA((1,2,6),1)

$$
\text { FIIS }_{t}=1.3701 \text { FIIS }_{t-1}-0.3329 F_{I I S} S_{t-2}-0.0401 F I I S_{t-6}+\varepsilon_{t}-0.9493 \varepsilon_{t-1}
$$

6) FIIN- Net Foreign Institutional Investment flow-ARMA(2,1)

$$
\text { FIIN }_{t}=1.0988 \text { IIN }_{t-1}-0.1589 \text { IIN }_{t-2}+\varepsilon_{t}-0.7899 \varepsilon_{t-1}
$$

The R-squared values for the above estimated models are $21.15 \%, 46.87 \%, 92.64 \%, 43.94 \%, 52.76 \%$ and $21.57 \%$ for equations $9-14$, respectively.

India being a capital scarce country has taken various steps to allure foreign investment since the beginning of globalization in 19991. India started receiving foreign investments in the form of institutional investments in 1993, and since then has become one of the main channels of Foreign Investments in India. Foreign Institutional Investors are an entity established or incorporated outside India that proposes to make investments in India and is registered as an FII under SEBI (FII) Regulations, 1995. Economic growth is a function of capital formation. AsForeign Institutional Investments are source of non-debt creating capital for receiving economy; many emerging economies have been competing with each other to attract such flows through flexible investment norms/regulations or by offering fiscal sops. Ever since the Flls were allowed to invest in Indian financial market, they have been criticized due to characteristics such as hot money (Stiglitz, 1999), herd mentality (Tayde\&Rao, 2011), feedback traders (Grinblatt\&Keloharju, 2000), short term speculative gains and their implications on domestic policy issues. Secondary markets offer opportunities for speculation, which leads to a situation where the players indulge in outguessing the market in foreseeing changes in the short-term financial ratios. This converts the secondary market into a quasi-casino where people speculate on other people's speculation (Keynes, 1936). Such speculative flows are inherently volatile and can play havoc at the time of sudden reversal. When investors flee from securities markets abruptly in a herd, the prices of bonds and shares are impacted. And when investors repatriate the redemption proceeds to their country, exchange rates go out of order. In such circumstances, if the Reserve Bank of India intervenes to bring orderly conditions into the foreign exchange market; liquidity will dry up in the money markets. Hence, speculative flows affect all segments of financial markets - the securities market, the foreign exchange market, the money market and the credit market-since systemic risk transmits from one market to another instantly and may lead to output and employment losses (Subbarao, 2010). As the Indian capital market is relatively thin due to a lower retail investment base (less than 10 per cent), FIl inflows will have a significant effect on the movement of stock prices (Srikanth and Kishore, 2012). Thus trends and future prospects of Flls have become a topic of great concern.

Though numerous research have been carried out to study Fll flows into Indian capital market, most of them have been confined to assessing the impact of such flows on stock markets. This is the first study to our knowledge, which uses extensive dataset to forecast FII flows towards India using ARIMA models. Albeit the specifications of all models are appropriate, one cannot rely completely on technical analysis - fundamental aspects, upcoming events and other major economic factors also play a major role in affecting Fll flows towards any country. Moreover, the R-squared value reveals what percent of variance is explained by the specified model. The higher the R-squared value, the better the predictability or reliance of the model.The global financial crisis, the direct impact of Lehman Brothers going bankrupt, the Euro zone crisis, depreciation of Indian rupee against US dollar, and curbs on Participatory notes issue are the main reasons for restricting the FII inflows into the Indian capital market. Moreover, all macro-economic factors whether country specific or global are inter-related, one cannot separate their effects. A shock to any economic factor would be channelized to all other economic factors, which can be seen in their values. The uniqueness of the research comes from the fact that this will help to develop better models as another forecasting tool for highly volatile Indian market and particularly Fll flows towards it. The use of high frequency data for longer time period tries to capture the effect of all ups and downs.

As an implication of this work, one can extend the established models for exploring a day to day volatility using volatility cluster models. However, for prediction at different times in future, the model may be trained periodically and needs to be revalidated with changes in some of the features of the model. It is believed that this study will give a promising direction to the study of prediction of the FII flow, markets and other economic time series, as very few studies are available for forecasting activities of FII. 


\section{REFERENCES}

[1] Abhyankar, A. (1998). Linear and nonlinear Granger causality: Evidence from the UK stock index futures market. Journal of Futures Markets, 18(5), 519-540.

[2] Ahmad, K. M., Ashraf, S., \& Ahmed, S. (2005). An Empirical Investigation of Flls role in the Indian Equity Market: A firm level analysis. The ICFAI Journal of Applied Finance, 11, 21-33.

[3] Ananthanarayanan, S., Krishnamurti, C., \& Sen, N. (2009). Foreign institutional investors and security returns: evidence from Indian stock exchanges. Paper presented at the Proceedings of the 7th INFINITI Conference on International Finance 2009-Credit Markets, Credit Institutions and Macroeconomic Volatility.

[4] Antoniou, A., \& Holmes, P. (1995). Futures trading, information and spot price volatility: evidence for the FTSE-100 stock index futures contract using GARCH. Journal of Banking \& Finance, 19(1), 117-129.

[5] Ariyo, A., Adewumi, A. O., \& Ayo, C. K. (2014). Stock Price Prediction Using the ARIMA Model. Paper presented at the Computer Modelling and Simulation (UKSim), 2014 UKSim-AMSS 16th International Conference on.

[6] Aruga, K., \& Cook, S. (2014). An intervention analysis on the Tokyo Grain Exchange non-genetically modified and conventional soybean futures markets. Cogent Economics \& Finance, 2(1), 918854.

[7] Bollen, N. P. (1998). A note on the impact of options on stock return volatility. Journal of Banking \& Finance, 22(9), 1181-1191.

[8] byJOHN MAYNARD, K. (1936). The General Theory of Employment, Interest, and Money.

[9] Calvo, G. A. (1998). Capital flows and capital-market crises: the simple economics of sudden stops.

[10] Calvo, G. (2009) July 14-15. Lessons from Systemic Financial Crises. Presentation at India Policy Forum 2009. New Delhi.

[11] Chakrabarti, R. (2001). Fll flows to India: Nature and causes. Money and Finance, 2(7).

[12] Chan, K., Chan, K. C., \& Karolyi, G. A. (1991). Intraday volatility in the stock index and stock index futures markets. Review of Financial Studies, 4(4), 657-684.

[13] Chen, C., Hu, J., Meng, Q., \& Zhang, Y. (2011). Short-time traffic flow prediction with ARIMA-GARCH model. Paper presented at the Intelligent Vehicles Symposium (IV), 2011 IEEE.

[14] Cho, M., Hwang, J., \& Chen, C. (1995). Customer short term load forecasting by using ARIMA transfer function model. Paper presented at the Energy Management and Power Delivery, 1995. Proceedings of EMPD'95., 1995 International Conference on.

[15] Choudhry, T. (1997). Short-run deviations and volatility in spot and futures stock returns: Evidence from Australia, Hong Kong, and Japan. Journal of Futures Markets, 17(6), 689-705.

[16] Dickey, D. A., \& Fuller, W. A. (1979). Distribution of the estimators for autoregressive time series with a unit root. Journal of the American statistical association, 74(366a), 427-431.

[17] Dickey, D. A., \& Fuller, W. A. (1981). Likelihood ratio statistics for autoregressive time series with a unit root. Econometrica: Journal of the Econometric Society, 1057-1072.

[18] Dong, H., Jia, L., Sun, X., Li, C., \& Qin, Y. (2009). Road traffic flow prediction with a time-oriented ARIMA model. Paper presented at the INC, IMS and IDC, 2009. NCM'09. Fifth International Joint Conference on.

[19] Dornbusch, R., Goldfajn, I., Valdés, R. O., Edwards, S., \& Bruno, M. (1995). Currency crises and collapses. Brookings Papers on Economic Activity, 219-293.

[20] El Hag, H., \& Sharif, S. M. (2007). An adjusted ARIMA model for internet traffic. Paper presented at the AFRICON 2007.

[21] Fan, S., Mao, C., \& Chen, L. (2007). Next-day electricity-price forecasting using a hybrid network. IET generation, transmission \& distribution, 1(1), 176-182.

[22] Geomelos, N., Xideas, E., \& McMillan, D. (2014). Forecasting spot prices in bulk shipping using multivariate and univariate models. Cogent Economics \& Finance, 2(1), 923701.

[23] George, B. (1994). Time Series Analysis: Forecasting \& Control, 3/e. Pearson Education India.

[24] Gordon, J. P., \& Gupta, P. (2003). Portfolio Flows into India: Do Domestic Fundamentals Matter?

[25] Griffin, J. M., Nardari, F., \& Stulz, R. M. (2004). Are daily cross-border equity flows pushed or pulled? Review of Economics and Statistics, 86(3), 641-657.

[26] Grinblatt, M., \& Keloharju, M. (2000). The investment behavior and performance of various investor types: a study of Finland's unique data set. Journal of financial economics, 55(1), 43-67.

[27] Gulen, H., \& Mayhew, S. (1999). Stock index futures trading and volatility in international equity markets.

[28] Gupta, O. (2002). Effect of introduction of index futures on stock market volatility: The Indian evidence. Paper presented at the Sixth Capital Market Conference.

[29] Hai-yan, Z. (2010). N days average volume based ARIMA forecasting model for Shanghai metro passenger flow. Paper presented at the Artificial Intelligence and Education (ICAIE), 2010 International Conference on. 
[30] Hetamsaria, N., \& Swain, N. (2003). Impact of the Introduction of Futures Market on the Spot Market: An Empirical Study. The ICFAI Journal of Applied Finance, 9(8), 23-36.

[31] Kumar, N., Kumari, P., Ranjan, P., \& Vaish, A. (2014). ARIMA model based breast cancer detection and classification through image processing. Paper presented at the Engineering and Systems (SCES), 2014 Students Conference on.

[32] Kumar, S. (2009). Investigating causal relationship between stock return with respect to exchange rate and FII: evidence from India.

[33] Lemmon, M. L., \& Lins, K. V. (2003). Ownership structure, corporate governance, and firm value: Evidence from the East Asian financial crisis. The journal of finance, 58(4), 1445-1468.

[34] Maniar, H. (2006). Impact and Role of Mutual funds in Derivatives markets-A Thematic Case study of Indian Capital Markets. Management Today - Journal of Management Science, 1.

[35] Márquez, F. P. G., Pedregal, D. J., \& Roberts, C. (2015). New methods for the condition monitoring of level crossings. International Journal of Systems Science, 46(5), 878-884.

[36] McKenzie, M. D., Brailsford, T. J., \& Faff, R. W. (2000). New insights into the impact of the introduction of futures trading on stock price volatility: CFA Institute.

[37] Mukherjee, K., \& Mishra, R. (2006). Lead-Lag Relationship Between Equities and Stock Index Futures Market and It's Variation Around Information Release: Empirical Evidence from India. NSE Research Paper, NSE India.

[38] Mukherjee, P., Bose, S., \& Coondoo, D. (2002). Foreign institutional investment in the Indian equity market: An analysis of daily flows during January 1999-May 2002. Money \& Finance, 2(9-10).

[39] Pericli, A., \& Koutmos, G. (1997). Index futures and options and stock market volatility. Journal of Futures Markets, 17(8), 957-974.

[40] Phillips, P. C., \& Perron, P. (1988). Testing for a unit root in time series regression. Biometrika, 75(2), 335346.

[41] Prasad, E., Rogoff, K., Wei, S.-J., \& Kose, M. A. (2003). Effects of financial globalization on developing countries: some empirical evidence (Vol. 17): International Monetary Fund Washington, DC.

[42] Saar, I. (2015). Do alcohol excise taxes affect traffic accidents? Evidence from Estonia. Traffic injury prevention, 16(3), 213-218.

[43] Shan, R., Dai, H., Zhao, J., \& Liu, W. (2015). Forecasting Study of Shanghai's and Shenzhen's Stock Markets Using a Hybrid Forecast Method. Communications in Statistics-Simulation and Computation, 44(4), 1066-1077.

[44] Shenbagaraman, P. (2003). Do futures and options trading increase stock market volatility? NSE News Letter, NSE Research Initiative, Paper(20).

[45] Srikanth, M., \& Kishore, B. (2012). Net Fll Flows into India: A Cause and Effect Study. ASCI Journal of management, 41(2), 107-120.

[46] Stiglitz, J. E. (1999). Lessons from East Asia. Journal of Policy Modeling, 21(3), 311-330.

[47] Subbarao, D. (2010). Volatility in capital flows: Some perspectives. Paper presented at the Comments to the High Level Conference organized by the IMF and Swiss National Bank, Zurich (11 May).

[48] Sudalaimuthu, S., \& Anbukarasi, M. (2011). Forecasting Monthly Foreign Institutional Investments in BSE and NSE Equity Market Using Arima Model.

[49] Tayde, M., \& Rao, S. (2011). Do foreign institutional investors (Flls) exhibit herding and positive feedback trading in Indian stock markets. Int Financ Rev, 12, 169-185.

[50] Thenmozhi, M. (2002). Futures trading, information and spot price volatility of NSE-50 index futures contract. NSE Research Paper, NSE India.

[51] Wang, W., \& Guo, Y. (2009). Air Pollution PM2. 5 Data Analysis in Los Angeles Long Beach with Seasonal ARIMA Model. Paper presented at the Energy and Environment Technology, 2009. ICEET'09. International Conference on.

[52] Yang, R., Li, L., Zhao, Z., \& Zhang, Y. (2013). Simulation of rain attenuation time series by ARIMA model. Paper presented at the Cross Strait Quad-Regional Radio Science and Wireless Technology Conference (CSQRWC), 2013.

[53] Ye, X. (2010). The application of arima model in chinese mobile user prediction. Paper presented at the Granular Computing (GrC), 2010 IEEE International Conference on.

JEL Classification Codes: C580, F410, G100, G230 


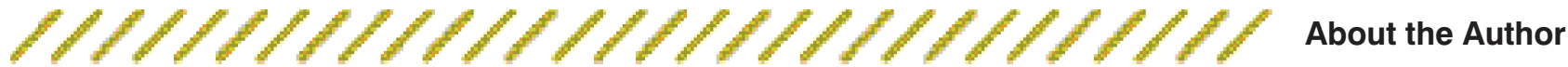

Dr. Vaishali S. Dhingra

S.V.National Institute of Technology (SVNIT), Surat, India Vaishalidhingra1@gmail.com

Dr.Vaishali S. Dhingra, MBA, works as a teaching assistant at the SVNIT, Surat, India, where she obtained her $\mathrm{PhD}$ degree. She has more than 7 years of experience in corporate as well as academic areas. She has attended many workshops, seminars and conferences at national and international levels. She has also co-authored many papers

in national and international journals. Her areas of interest are Security Analysis and

Portfolio Management, Quantitative Analysis, Econometrics and Time Series Analysis.

\section{Dr. Hemantkumar P. Bulsara \\ S.V.National Institute of Technology (SVNIT), Surat, India hemantbulsara@gmail.com}

Dr.Hemantkumar P. Bulsara received his Bachelor of Engineering (Production Engineering) degree from S. V. National Institute of Technology (NIT), Surat, India and Double MBA from DBIM, VNSGU, Surat, India. He did his FDPM from the Indian Institute of Management, Ahmedabad (IIM A), India and completed his Ph.D. from S. V. National Institute of Technology (NIT), Surat, India. At present, he is an assistant professor (Economics \& Management) and In - Charge of Management section at S. V. National Institute of Technology (NIT), Surat, India. He has more than 15 years of experience. His areas of research are Technology Innovations and Entrepreneurship, Technology Business Incubation, Marketing Management, Strategy and Supply Chain Management.

He has more than 50 publications. He is an editorial board member and reviewer of several national and international Journals of repute. He has been a keynote speaker, Conference chair and a session chair at national and international levels. He travelled to many countries such as USA, UK, France, Netherlands, Italy, Bali Indonesia, Hong Kong, Macau, Thailand, Malaysia, Singapore, Finland, etc.

Dr. Shailesh Gandhi Indian Institute of Management (IIM), Ahmedabad, India shailesh@iimahd.ernet.in

Dr. Shailesh Gandhi is currently the chairperson of 2-year Post Graduate Programme in Management (PGP), the flagship programme of IIMA. He has more than 28 years of experience in consultancy, industry and academics. The consulting experience includes working with several organizations in both private and public sectors and also on the assignments funded by international agencies such as the World Bank, OECF, ICA, the Royal Netherlands Embassy, etc. The consulting areas include: financial restructuring, business systems development, accounting \& costing systems and corporate performance measurement. His industry experience comes from the areas of corporate finance, accounting and MIS in chemical companies. The academic experience includes teaching and research in the Finance and Accounting Areas.
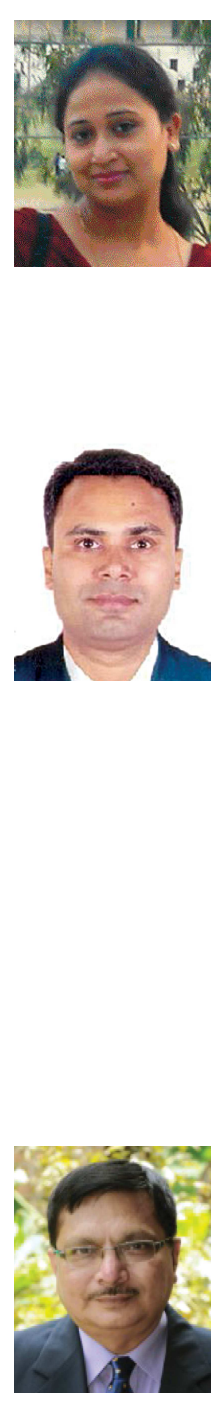